Jakub Brdulak', Jacek Lewicki², Jan Beseda ${ }^{3}$, Ida Kristina Kühn ${ }^{4}$, Lisa Meyne ${ }^{5}$, Gunta Kinta ${ }^{6}$, Edmunds Labunskis ${ }^{7}$

\title{
The development of graduates' social competences. The case studies from four European universities in the context of higher education public policy in Poland, Germany, Latvia and the Czech Republic. The outcomes of the Erasmus+ DASCHE project
}

\begin{abstract}
The Bologna Process indicates that preparation for living as active citizens in a democratic society is one of the main purposes of higher education. Moreover, other relevant European strategies postulate that social competences development in HE graduates as well as the European Qualifications Framework should comprise the pillar of 'competences: autonomy and responsibility' The United Nations and OECD emphasise the role of education and developing social competences, too.

Higher Education Institutions' (HEIs) educational mission involves the transfer of knowledge and skills, as well as shaping the social competences of students. This article aims to show good practices in the development of students' social competences by different HEIs. Based on the cases the findings were formulated that the development and assessment of social competences in HEIs is possible, however, one standardised solution cannot be developed. Diversity is crucial in the presented programmes. Our main recommendation is to create room for debates about social competences in the researched countries and in the whole EHEA.

\footnotetext{
SGH Warsaw School of Economics, Poland, https://orcid.org/0000-0002-7772-7721

SGH Warsaw School of Economics, Poland, https://orcid.org/0000-0001-8690-9626

3 Centre for Higher Education Studies, National Centre for Distance Education, the Czech Republic, https://orcid.org/0000-0002-1733-7617

4 University of Bremen, Germany, https://orcid.org/0000-0002-8026-5521

MA student of University of Bremen, Germany, https://orcid.org/0000-0002-0223-4754

Academic Information Centre, Latvia, https://orcid.org/0000-0002-8333-6911

7 Academic Information Centre, Latvia, https://orcid.org/0000-0002-7801-4053
} 
Keywords: social competences, higher education, education for the future, curricula, social engagement

\section{Streszczenie}

Proces boloński zakłada m.in., że przygotowanie absolwentów do życia jako aktywnych obywateli w społeczeństwie demokratycznym, jest jednym z głównych celów szkolnictwa wyższego. Również inne strategie europejskie zakładają, że rozwijanie kompetencji społecznych absolwentów szkół wyższych, powinny stanowić filar Europejskich Ram Kwalifikacji w zakresie „autonomii i odpowiedzialności”. ONZ i OECD również podkreślają rolę edukacji w rozwijaniu kompetencji społecznych.

Misja edukacyjna uczelni obejmuje przekazywanie wiedzy i umiejętności, a także kształtowanie kompetencji społecznych studentów. Niniejszy artykuł ma na celu przedstawienie dobrych praktyk w tym zakresie. Na podstawie przytoczonych studiów przypadków sformułowano ustalenia mówiące o tym, że rozwijanie i ocena osiągnięcia kompetencji społecznych w uczelniach jest możliwa, jednak nie można wypracować jednego znormalizowanego rozwiązania. Różnorodność ma kluczowe znaczenie w przypadku prezentowanych przykładów. Głównym zaleceniem wynikającym z projektu DASCHE jest postulat stworzenie przestrzeni do dyskusji na temat kompetencji społecznych w badanych krajach i całym Europejskim Obszarze Szkolnictwa Wyższego (EHEA).

Słowa kluczowe: kompetencje społeczne, szkolnictwo wyższe, edukacja dla przyszłości, programy kształcenia, zaangażowanie społeczne

\section{Introduction}

In recent years, there has been a noticeable shift to broadly defined social competences in higher education. This approach is motivated by the need to prepare people for an uncertain future determined by rapid social and technological changes. Social competences and complex knowledge are crucial for understanding the world and encourage people to engage into its transformation. The ideas of an 'education for the future' or 'ownership of the future' (e.g. Collins \& van der Wende, 2002; Teichler 2003) reflect this attitude, too.

The need to prepare graduates for these challenges of the future was recognised; they need to be well-equipped to face the complexity, diversity and permanent change of their natural and social environment. Academic teachers, as well as policymakers, postulate acquiring broader knowledge, not limited to a narrow cognitive and professional field, but comprising issues related to cognition, culture and society, 
fostering social responsibility. Graduates are to be equipped with strong cognitive and practical skills of transitory nature (such as communication, problem-solving, an ability to apply the acquired knowledge in practice) and some narrower practical skills related to the main field of study (definition(s) of social competences, see: Brdulak, Chmielecka et al., 2020: 8-9).

To design and deliver an effective process of forming students' social competences is a real challenge for higher education institutions (HEIs). In the article the programmes devoted to social competences formation are presented, run by HEIs located in 4 countries: Poland, Germany, Latvia and the Czech Republic, which are perceived by the authors as good practices in the development and assessment of social competences. The paper was based on the outcomes of the DASCHE Project (Erasmus+). ${ }^{8}$

\section{Social competences and challenges of the future}

Social competences, transitive competences or attitudes are increasingly becoming the subject of interest of higher education researchers or, generally, education. Due to very fast technological advances and related changes on the labour market, many authors pay attention to social competences in a professional or educational and training (VET) context (Mulder, Weigl \& Collins, 2006; Sá, Serpa, 2018; Oria, 2012; Macioł, 2012; Szerląg, 2009). Moreover, universities constitute one of the elements of broadly understood lifelong learning (LLL) (e.g. Boyadijeva \& Ilieva-Trichkova, 2018; Walker \& McLean, 2013). Another very important aspect of social competences, exceeding the sphere of professional life, are attitudes related to broadly understood social and public life. As in the case of the professional aspect, also in this area of the study of social competences, there is a vast array of literature related to lower levels of education (e.g. ten Dam, \& Volman, 2007). Since the beginning university has been a place of education and forming elites, consequently, shaping competences for social and public life remains its important, yet not always direct or explicit purpose. Therefore, in the face of changes in higher education, related to, among others, its massification and the subsequent marketisation of higher education as well as social changes, the place of broadly understood social competences in higher education requires a new definition (e.g. Giroux, 2014; Gedviliene et al., 2014).

The framework of the current (2018-2020) perspective of the Bologna Process was formulated by the EHEA Ministers in the Paris Communiqué of May $25^{\text {th }}, 2018$.

\footnotetext{
8 More information about DASCHE in section 3 of this paper.
} 
In the previous perspective, educating students for the needs of the labour market was particularly emphasised. The Paris Communiqué focused on the social competences of students, directly referring to the sustainable development goals formulated by the United Nations (UN):

"We commit to developing the role of higher education in securing a sustainable future for our planet and our societies, and to finding ways in which we, as EHEA Ministers, can contribute to meeting the United Nations Sustainable Development Goals at global, European and national levels." (Paris Communiqué, 2018)

The United Nations General Assembly adopted the resolution of September $25^{\text {th }}$, 2015 Transforming our world: the 2030 Agenda for Sustainable Development and The 17 Sustainable Development Goals, ${ }^{9}$ Goal 4 directly refers to education and is called "Ensure inclusive and equitable quality education and promote lifelong learning opportunities for all". The description of this goal highlights, among others:

"4.7. By 2030, ensure that all learners acquire the knowledge and skills needed to promote sustainable development, including, among others, through education for sustainable development and sustainable lifestyles, human rights, gender equality, promotion of a culture of peace and non-violence, global citizenship and appreciation of cultural diversity and of culture's contribution to sustainable development" (UN, 2015).

Thus, challenges related to the implementation of the above objectives (of the UN as well as EHEA) require higher education which focuses more on social competences.

The OECD is another international institution that provides a global analysis of challenges of the future and relevant changes in education. In 2018, the publication The future of education and skills. Education 2030 was published, in which it is stated as follows:

"We are facing unprecedented challenges - social, economic and environmental - driven by accelerating globalisation and a faster rate of technological developments. At the same time, those forces are providing us with myriad new opportunities for human advancement. The future is uncertain, and we cannot predict it; but we need to be open and ready for it. [...] Schools can prepare them [children] for jobs that have not yet been created, for technologies that have not yet been invented, to solve problems that have not yet been anticipated. To navigate through such uncertainty, students will need to develop curiosity, imagination, resilience and self-regulation (...)." (OECD, 2018: 2).

9 The 17 UN Sustainable Development Goals are: 1) End poverty in all its forms, 2) Zero hunger, 3) Health, 4) Education, 5) Gender equality and women's empowerment; 6) Water and sanitation, 7) Energy, 8) Economic growth, 9) Infrastructure, industrialization, 10) Inequality, 11) Cities, 12) Sustainable consumption and production, 13) Climate change, 14) Oceans, 15) Biodiversity, forests, desertification, 16) Peace, justice and strong institutions, 17) Partnerships. 
The OECD strongly emphasises that the role of education isto develop social competences. Furthermore, the report underlines that the concept of competence involves "the mobilisation of knowledge, skills, attitudes and values to meet complex demands" (OECD, 2018: 5).

International analyses conducted by higher education stakeholders also indicate this trend. A report published by the European University Association entitled Trends 2018. Learning and teaching in the European Higher Education Area seems to be particularly interesting. This report presents the results of European universities' research in the field of learning and teaching. One of the questions addressed by the academia concerned the so-called social inclusion and social involvement. Universities were asked whether social inclusion and social involvement have any impact on education. The answer to the above question is presented in the chart:

At your institution does inclusiveness and social engagement have any impact on learning and teaching? (Q. 28; $N=288$, in \%)

The institution encourages student initatives on civic/social engagement

Social inclusion is key priority of our institutional strategy

Social inclusion is considered in the learning and teaching practice (diverse classroom)

Social engagement is integrated into the study programmes (internships with NGOs, community engagement, etc.)

Students can earn credits through participation in civic/social engagement initiatives

There are special courses in social engagement
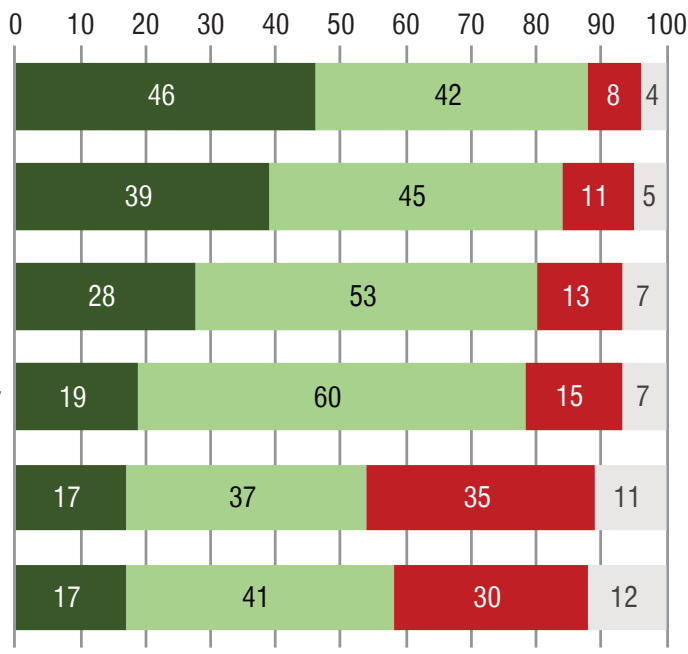

YES $\square$ TO SOME EXTENT/IN PARTS OF THE INSTITUTION $\square$ NO NO INFORMATION/NOT APPLICABLE

\section{Chart 1. Impact of inclusiveness and social engagement on learning and teaching}

Source: EUA, 2018: 46.

In this case, part of business and part of the academic world seem to share the same opinion in the public forum, and not only in a small group of experts - " [...] the world order [is] going to get more complicated and challenging to navigate and manage, increasing the need for people with accumulated wisdom, interpersonal and 
practical competence, and more than a splash of critical thinking, analytical reasoning, and altruism" (Kuh, 2019).

The above quotations illustrate the growing importance of shaping social competences of higher education graduates and create a stimulation to undertake research in the framework of the DASCHE project.

\section{The DASCHE project}

The main objective of the DASCHE project ${ }^{10}$ is to support learning policy across countries and Higher Education Institutions in development, assessment and validation of learning outcomes relevant for social competences. The specific objectives are formulated as follows:

1. A detailed analysis of the ways of forming social competences by HEIs adopted in different countries including: incorporating social competences in the scope of qualifications awarded by HE; teaching/learning and assessment/examination methods; responsibilities of HEIs and other institutions; standards, criteria and processes of external and internal quality assurance; continuous debate on the development of social competences.

2. Based on the analysis models and methodologies of introducing and assessing learning outcomes linked to social competences in the formal HE qualifications will be identified, further developed and incorporated in the DASCHE recommendations addressed to the project participants. (DASCHE IO1, 2018)

Qualitative methods serve as the main source of information. Qualitative methods are relevant, due to the diversity of approaches to social competences in different national systems and institutions. 28 case studies - examples of good practices - were elaborated in the framework of the project. The main elements of the methodology adopted by DASCHE (Dasche IO1, 2018) are as follows:

- selecting the HE institutions and their units for case studies (due to, among others: differentiation in sizes and types of HEIs, different disciplines of education);

10 The partners of the project represent the following institutions: SGH Warsaw School of Economics (project leader, Poland), Twente University (the Netherlands), University of Bremen (Germany), Durham University (the United Kingdom), Academic Information Centre (Latvia), Centre for Higher Education Studies (the Czech Republic). The associated partners of the DASCHE project are as follows: the Council of Higher Education of Latvia, University of Cologne (Germany), the Czech Rectors Conference, the National Representation of the PhD Candidates in Poland, The European Council of Doctoral Candidates and Junior Researchers EURODOC, The Polish Accreditation Committee, The National Council for Science and Higher Education (Poland), The Conference of Rectors of Academic Schools in Poland and the Polish Rectors Foundation, The Students' Parliament of the Republic of Poland, The National Unions of Students in Europe ESU. For more information see: http//dasche.eu 
- desk research of strategic national and institutional documents;

- field research - individual in-depth interviews (IDI) with senior management staff at the HEIs;

- field research - focus group Interviews (FDI) with teachers;

- field research - focus group Interviews (FDI) with students;

- consulting the findings and recommendations with external associated stakeholders (seminars, IDIs).

Examples of questions (Dasche IO1, 2018: 19):

- What standards and criteria of evaluation are dedicated to learning outcomes relevant for 'social competences'?

- Are there criteria specifically dedicated to them?

- What are the QAA's reasons for this approach to assessing learning outcomes relevant for 'social competences'?

- What evidence is required from higher education institutions to confirm the achievement of 'social competences' by students/graduates?

- How is achievement of 'social competences' by students/graduates assessed in the process of external evaluation (i.e. during site visits)?

- How does the QAA evaluate HEIs/study programmes to improve higher inclusion and better verification of 'social competences'?

- How does the QAA motivate HEIs/study programmes to improve higher inclusion and better verification of 'social competences'?

- How (criteria and procedures) does the QAA assess whether the expected learning outcomes for social competences are appropriately designed and validated?

- What is the impact of evaluation of 'social competences' (design - validation - achievement) on the final evaluation of the assessed HEI/study programmes?

\section{The DASCHE project and selected findings}

In this section 4 case studies are outlined; they serve as examples of good practices, presenting in a very synthetic way how the selected HEIs design and deliver programmes focused on social competences of students in the context of national and institutional policies. 


\section{School of Business and Finance (BA), Latvia}

The BA School of Business and Finance is one of the leading, self-financing business HEIs in Latvia, located in the city of Riga. It was founded in 1992 as the Banking College under the Bank of Latvia. The BA has approximately 1,490 students and offers 14 study programmes. The BA provides study programmes of all three Bologna cycles, including the short cycle. Its main focus is on finance and business studies. All the study programmes comprise company internship as a compulsory component. The study process has gained an international dimension. Every year the BA receives international full-time and exchange students, which contributes to forming a diverse student community.

In the Strategy of the BA School of Business and Finance 2018-2023 we can find a chapter titled "Assuring $21^{\text {st }}$ century skills in study programmes", which defines the main and most desirable skills in 2020, including social competences (e.g. cooperation with others, intercultural communication, interdisciplinary communication). The Action plan for the development of academic staff of the BA School of Business and Finance identifies the need to develop new skills and competences (e.g. an ability to implement leadership effectively).

The document analysis has revealed that there is no separate policy set for defining, developing and evaluating social competences at the BA; however, they are incorporated in the study process and the HEI policy.

As the results of the interviews demonstrate, the goal of higher education is positioned at two levels: the externally targeted objectives and the self-growth of an individual in a society. Higher education provides students and graduates with an ability to implement and realise their self-education, which allows for achieving further goals in their careers.

Regarding the role of social competences, HEI representatives compared the development of higher education with social competences - an individual has to achieve a satisfactory level of social competence to obtain a diploma. The development of social skills is important at any level of education and is a rolling theme in any content that strengthens the ability to collaborate effectively through socialisation. Social competences mean an ability to cooperate. In the context of higher education, a student in a similarly minded environment has an opportunity to learn to cooperate better, to share knowledge, to respect the needs of others, to jointly think about their future career. In higher education social competences are an integral part of the entire study process - for example, in group work, where the division of responsibilities is formed. 
As an example of a good practice, group work in study courses and content discussions were highlighted. The development of social competences typically takes place indirectly and incidentally; social competences are not specifically targeted in the study courses. In some study courses, students are encouraged to leave their comfort zone, which helps them adapt to different situations; thus, also improving their social competences.

There are many challenges regarding the development of social competences in higher education. The representatives of HEIs pointed out that students lack basic social skills such as accepting discipline, respecting others, planning, meeting deadlines, taking responsibility, delivering promises, telling the truth, and adequately expressing feelings. Digitisation was described as the greatest challenge to interpersonal communication. Due to digitisation, people have less face-to-face conversations and often communicate through text messages, which leads to a loss of necessary communication skills and being unable to express their opinions clearly.

\section{University of Konstanz, Germany}

Since the Bologna agreement in 1999, the higher education system in Germany has been reorganised, moving from a one- to a two-stage model. The process of studying itself became more compatible at the national and international levels. Examinations, including their allocation within the qualification levels, as well as related goals regarding qualifications and competences of graduates are established within the German Qualification Framework for Higher Education Qualifications (HQR). To ensure the comparability of qualifications, it is necessary for organisations as well as for the structure of study courses to be oriented towards the fundamental conditions, presented by the Standing Conference of the Ministers of Education and Cultural Affairs (KMK). Since 1999, a nationwide accreditation system has been functioning, and it is supervised by the Accreditation Council (AC) under the auspices of the Foundation for the Accreditation of Study Programmes in Germany (FASPG). ${ }^{11}$ New study courses may carry the quality label of the accreditation council provided that accreditation ${ }^{12}$ has been granted.

The University of Konstanz represents one of four cases of the German study, which includes approx. 11,268 students, where $12 \%$ of them represent other countries.

11 View also: http://www.akkreditierungsrat.de/index.php?id=44\&L=1\&contrast=1\%27\%22 (accessed: 10.04.2018).

12 German Rectors' Conference, retrieved from: https://www.hrk.de/uploads/media/Das_Hochschulsystem_In_DEUTSCHLAND.pdf (accessed: 10.04.2018). 
The University structure comprises sections and assigned departments, which makes the University different in its structure from other commercial universities in Germany. ${ }^{13}$ Research and teaching processes are explicitly outlined in the mission statement and guiding principles ${ }^{14}$ of the University. The reference to social competences is also included in different quotes like 'contribution to the self-enlightenment of society', 'ethical reflection of science on its methods and the consequences of its results for people and the world', 'development of personalities' and 'it [the HEI] follows the principles of sustainability in its social [...] processes'. Moreover, the institution defines a 'culture of creativity' as 'transparent, participative processes of decision making' and 'clear responsibilities'. 'Profession and performance' define hierarchies, 'discussions in committees have to be open to everybody'.

Five study courses at the BA and MA levels were analysed in this case. They represented business, pedagogics and life sciences, which have references to social competences. Two of them refer to social competences directly in the learning objectives of the course, which shows a strong reference to the structural level. The description of these study courses indicates competences such as an 'ability to deal with conflict and criticism', an 'ability to work in a team', 'empathy', 'assertiveness' and 'leadership qualities', as well as other social techniques ${ }^{15}$ such as a 'critical-reflective evaluation of the results', an 'ability to argue and solve problems in both research and practice' and 'communication competences, which include a reflected summary and communication of findings' as well as an 'ability to deal with conflicts and criticism', 'moderation and communication skills', 'international orientation'. Three other courses do not refer explicitly to social competences in their formal documents. There are some competences named which could refer to social competences indirectly, they involve 'learning and motivation', 'teaching and assessment (teaching profession)' and 'critical questioning of both the teacher's own personality and performance. Following the analysis, it can be stated that social competences are addressed more thoroughly in the formal documents of bachelor courses. Master courses, however, are focused more on professional qualifications and work-related techniques. ${ }^{16}$

Based on the interviews conducted it has been found that social competences are regarded as the main goals of higher education. Nevertheless, social competences are not included in more formal descriptions of study courses. As regards the

13 Retrieved from: https://www.uni-konstanz.de/en/university/faculties-and-departments/) accessed: 04.2019).

14 Retrieved from: https://www.uni-konstanz.de/en/university/about-the-university-of-konstanz/ profile/mission-statement/ (accessed: 04.2019).

15 cf. University of Bremen 2019, 39.

16 cf. University of Bremen 2019, $40 \mathrm{ff}$. 
organisation, the responsibility to introduce social competence development is seen as an objective to be met by the faculties. However, the faculties treat this requirement with a diversified degree of reflection. The universities are more focused on the requests of the academic labour market. ${ }^{17}$ "A curricular embedding of special didactical concepts of fostering social competences, such as service learning, is not given." (University of Bremen, 2019: 43)

There is also a hurdle related to the integration of social competence development in the study courses and modules, because the lecturers seem to lack knowledge on how they should do it in practice. In spite of it, the case of the University of Konstanz has demonstrated that there are several examples of good practices. For instance, the University offers courses about intercultural interrelations, which young scientists should show in new working contexts. The course comprises several seminars which are completed with a certificate. Another example is an opportunity for teachers to reduce their teaching load and develop new concepts for teaching and learning or revise their previous concepts. As an example of a similar activity we can mention an internal competition, called Freedom for teaching, aimed at improving teaching at universities. The concept of a 'transfer in teaching' can be presented at this point serving as another example of a best practice at the University of Konstanz. Teachers or students enjoy an opportunity to initiate learning projects involving different target groups, both academic and non-academic. The initial project evolved into a well-established module at the university; consequently, students get a chance to gain experience while cooperating with external partners.

In this case social competence can be defined in three different dimensions. The first one involves the level of academic profession. Another perspective is offered by the work environment. The third dimension is constituted by key competences of societal relevance. Different definitions of social competences imply different performance ranges or levels. Consequently, developing social competences appears to be a subordinated goal of less importance than the development of academic profession. The results of the interviews show that the respondents surveyed describe the environment of higher education as quite competitive, whereby the position of social competences seems to be clear. Social competences can play a key role in making the competition in higher education fair and appreciative.

With regard to the desire to teach social competences at universities, students are the driving force, rather than the institution itself. Teachers believe that it is their task to transmit specific attitudes and values to their students, which remains inconsistent with the managing direction of the University focused more and more

17 cf. University of Bremen 2019, $41 \mathrm{ff}$. 
on employability of students in the labour market. The examples of best practices of the University of Konstanz demonstrate that students are definitely interested in project-based learning concepts, where they can acquire and apply social competences in real situations. ${ }^{18}$

The final outcomes all the German cases show (similar to the findings at the University of Konstanz) is that social competences are not discussed in formal documents regarding higher education. They are rather part of a hidden agenda; a discussion regarding formal introduction of social competences in higher education seems to be difficult. Consequently, the understanding of social competences bases on the 'concept of competences' formulated by Weinert (2001), where social competences are seen as a personal trait. Moreover, social competences are settled at an individual level and depend significantly on teaching persons. It lacks a clear description of learning objectives and reasonable forms of exams in higher education, there are also no descriptions in the study programmes and modules. The findings of the study clearly demonstrate that the description of some examples of good practices has been formulated at a general level.

There is a variety of recommendations regarding the introduction and development of social competences in higher education. In the case of the University of Konstanz, it has been emphasised that there is a need for developing comprehensive networking with other faculties, putting an end to financial cutbacks, highlighting the importance of teaching and offering teachers more free space for creativity. These issues must be noticed by the leadership of higher education, teaching in general must play a more important role in education policies. In addition to other recommendations resulting from different cases, there is a necessity of forming a conceptual framework for the development of social competence and its orientation in higher education. Also, there is a need for conducting research and developing literature on the topic, as well as considering social competences in general appointment procedures. At the national level, there is a need for preparing a collection of best practices in teaching, developing exchange programmes by institutions and communities in higher education; and changing organisational cultures. Furthermore, there is a need for national funding for projects aimed at developing social competences in higher education, basing on a bottom-up approach. At the European level, more information is required by the European Commission on transferring opportunities of social competence teaching/learning in a higher education system. ${ }^{19}$

18 cf. University of Bremen 2019, 44.

19 cf. University of Bremen 2019, $61 \mathrm{ff}$. 


\section{University of Economics and Management (UEM), Prague, the Czech Republic}

Social competences are not clearly visible in the Czech National Qualification Framework system. "The National Qualifications System represents the qualifications system in the Czech Republic; it is controlled by the government under the Act on the Recognition of Further Education Results (Act No. 179/2006 Coll.). The National Qualifications System refers to any bachelor, master and doctoral degree programmes under the Higher Education Act, as well as accredited education programmes at tertiary vocational schools in compliance with the Education Act." (Nantl, Černikovský, 2010: 22). The Ministry of Education, Youth and Sport has been paying more attention to the development of competences recently. The new and currently discussed strategy New Directions of Education Policy till 2030+ contains a chapter about developing active competences relevant in citizenship, work and daily life. The same competences are also listed in the Czech Strategic Framework for Sustainable Development 2030. ${ }^{20}$ Also, a specific strategy for the development of higher education $2022+$, which is being prepared now, is focused on the development of competences.

The UEM is a small private higher education institution located in Prague, which has been offering study programmes in economic and social sciences since 1996, currently with approximately 1,900 students. The UEM runs study programmes with specializations in Human Resources, Finance, Marketing, Advertising, Economics, Economic Policy, Law, Management, International Relations, Business and Organisational Culture, Psychology, Sociology, and Public Administration. Students can obtain Bachelor's and Master's degrees under both Czech and American accreditation (however, none of them pay any particular attention to the acquisition of social competences). All Czech HE study programmes are profession-oriented.

The selection of the UEM for the DSSCHE research was conducted, as it focuses on the development of students' skills and abilities in communication, presentation, argumentation, analysis, negotiation and teamwork - all of them are social competences, yet predominantly professionally oriented. What is more, the UEM develops activities related to the social responsibility of business with some elements of active citizenship. The UEM has the Code of Ethics, with the underlying idea of tolerance and openness for a variety of cultures, ideas or nationalities creating a friendly environment for students representing different social and national backgrounds. The

20 https://www.vlada.cz/assets/ppov/udrzitelny-rozvoj/Strategicky_ramec_Ceska_republika_2030compressed-_1_.pdf (accessed: 09.2019). 
university supports Quiet Café, employing deaf waiters, which also helped students to raise their awareness of the problems of vulnerable people. The UEM actively supports its students from other (also non-democratic) countries, helping them with getting a visa and study fee funding. The study groups are typically diversified in terms of age, ethnicity, gender, etc. The UEM has its own kindergarten, which allows the parents with young children to continue their studies.

The UEM is a small, private, non-university type of school, making efforts to use active learning methods and strongly supporting the idea of Corporate Social Responsibility in business. The HEI provides interactive teaching and examination applications (video learning, online video forums, educational texts in electronic form, electronic knowledge testing). The experience gained during the process of international accreditation may also influence the HEI's approach towards the issue of social competences.

The University has a strategic vision of the development of social/professional competences in their students, which is implemented in the form of special courses developing such competences. The UEM offers so called 'nanodegrees' (sub-degrees, specialisations) in the following areas: Communication and Society, Management and Leadership as well as Self-Development. Students can obtain nanodegrees after successful completion of a certain number of courses grouped in Modules. All of them comprise courses devoted to social competences - both explicitly and implicitly. For instance, a course of CSR is obligatory for all students. They can also design socially responsible start-ups (e.g. by working in teams); this exercise is a component of the SCR course. Another option is cooperation with NGOs on similar projects (e.g. with People in Needs, ${ }^{21}$ a local community in Prague 13, where the campus of the UEM is located) or with the Association of Corporate Social Responsibility which is a partner of the UEM. The university offers assistance in obtaining EU funds for these activities. Students use bricks with the United Nations Social Development Network goals ${ }^{22}$ for interactive discussion about the quality of life, sustainable development and corporate social responsibility.

During examinations students are supposed to present and defend seminar papers before an audience and the jury composed of teachers, which helps them to develop communication and argumentation skills. Similarly, critical thinking is enhanced by debates or seminars where various points of view are presented. Also, the UEM typically offers courses in blocks of 3 hours, which students perceive as very useful. Each study block consists of a lecture and a short break followed by a seminar/training/workshop.

${ }_{21}$ People in need is one of the the biggests Czech charitable NGOs (https://www.clovekvtisni.cz/en/)

22 https://unsdn.org/about-unsdn/ 
In students' opinions, also the organisation of the teaching/learning process helps them in developing social competences. A relatively flexible timetable and a possibility to select courses increases their autonomy in designing their learning path, as well as responsibility for the study programme. The UEM Guidelines for students helping to develop time management, improve their skills of organising studies and enhancing their independence of choices are evaluated by students as quite helpful. Students tend to criticise multiple choice tests, whereas debates and presentations are appreciated as helping them develop critical thinking and argumentation. Workshops on negotiation and presentation skills are indicated as the most effective activities in this aspect.

Based on this case, we can see some similarities to the German case: social competences can be seen as a kind of a side-effect of formal teaching within the framework of the national system of tertiary education. At the same time, however, the Quality Assurance Agency does not seem to motivate the HEI to specifically develop or assess social competences.

\section{The State University of Applied Sciences (PWSZ) in Elbląg, Poland}

The PWSZ in Elbląg is a young higher education institution established on July 1, 1998. Its mission statement declares that the School supports social, technological and cultural development of Elbląg and the region, in cooperation with all the political, social and economic organisations sharing similar objectives. Since its foundation, the School has issued approximately 10,000 diplomas. Almost half of the students originate from rural areas. Currently the PWSZ in Elbląg provides education to almost 3,000 students in eleven fields of $1^{\text {st }}$ cycle studies (Bachelor and engineering), offered by the Institutes of Applied Informatics, of Technology, of Pedagogy and Languages and of Economics. The HEI also conducts $2^{\text {nd }}$ cycle studies in Pedagogy (MA). All the programmes offered by the University have been accredited by the State Accreditation Committee. Theoretical knowledge acquired by the students at the University is complemented by the skills referring to its application during students work placements offered by the best companies in Elbląg.

The national context of the higher education public policy is specified by the Polish legislation. One of its requirements is designing each study programme basing on the level descriptors for higher education listed in the Polish Qualifications Framework (PQF). The descriptors represent 3 basic groups: knowledge (knowing and understanding), skills (being able to do) and social competences (being ready 
to do). In view of this, each HE programme in Poland, by law, comprises a component of social competences defined in accordance with the PQF descriptors and their interpretation. The programmes must be described with regard to learning outcomes and with reference to the PQF descriptors, which also comprise the area of social competences. For every 'non-humanistic' study programme 5 ECTS must be collected by every student following the completion of courses on humanities or social sciences issues.

The main reason for selecting the PWSZ in Elbląg for research was the HEI's clear and explicit strategy of developing social competences in students and supporting this process by an initiative which is unique in Polish higher education to create a programme (module) and a unit (centre) intentionally and explicitly aimed at the development of social competences. The programme is a compulsory element of vocation-oriented regular programmes.

- The module comprises two main elements:

- a reflection on various social competences embedded in traditional courses (lectures, seminars, konwersatoria - a form of classes including elements of a lecture and seminar), and

- pro-social activities of students evaluated by tutors and offering ECTS credits. ${ }^{23}$

- Building the "Social Competence Centre" (a contract between the HEI and central and local authorities) - to create space for various students' initiatives developed as part of the "Social Competences Module" (SCM) requiring suitable resources. Giving floor for students' research groups, for pro-social activities addressed to the local environment (e.g. children, disabled people, preventing environmental pollution), other initiatives. The support of the HEI in raising funds for those activities was declared by the Rector and confirmed by students during the interviews.

Why did the PWSZ undertake the initiative? Two types of motivation can be listed here.

Bottom-up motivation: defining the mission of PWSZ of contributing to the region's social and cultural development by forming relevant competences in graduates. In this respect well-established and good relations with the local social community are worth mentioning, as well as the Rector's and the staff's responsibility to educate and form high-qualified graduates - professionals and active members of the local community.

23 ECTS credits are granted for the completion of an entire module (0.25 ECTS per semester, 2 ECTS in total). 
The local authorities support the initiative (also financially - by providing funding for the Centre).

Personal involvement of the Rector in developing social competences of students is also crucial, combined with the PWSZ staff's dissatisfaction with the previous approach to forming social competences, which was their response to and a side-effect of some courses granting 5 ECTS. A need for intentional and focused reflection on graduates' social competences and the ways of forming them seemed to be a natural consequence of the situation observed.

Top-down motivation, which is predominantly a consequence of the public policy orientation within the framework of Polish higher education, and inspired by European systems as well as by the Bologna Process, with the idea and implementation of the Lifelong Learning strategy, with regard to the European Qualification Framework. - PQF requirements: the Act on Higher Education and Science and the Polish Qualifications Framework require incorporating social competences over the process of curricula design.

- The impulse to introduce a new course (module) compulsory for all students (all the curricula) came from the PWSZ's authorities. However, the practical details and implementation were designed by faculty members representing all the fields of studies.

How is the 'social competences' module (SCM) composed and how are the learning outcomes verified?

All the courses and practical activities of the module are focused on the development of a variety of social competences. 'The social and professional culture' module is provided over $2-5$. semesters of studies and consists of a series of lectures and seminars such as:

- Satisfactory life: personal and interpersonal competences;

- Self-management: self-consciousness, self-regulation, motivation;

- Problem-solving: making decisions, taking responsibilities;

- Human relationships and IT communication, etc.

All the learning outcomes of the courses cover social competences - they are described with the use of PQF terminology - the descriptors of level 6 devoted to social competences were developed. The methods of verifying the LO completion include:

- For the theoretical component of the module - regular forms of examination: typical forms of students' activity - essays, debates.

- For the practical component of the module - a portfolio and other evidence confirming the completion of the learning outcomes - evaluation provided by teachers/tutors. Two types of activities can be evaluated: (1) The activities listed by the PWSZ, such as volunteering organised by the PWSZ, promotion actions, 
selected students research-oriented activities, school choir, theatre, students' self-government bodies, etc. (2) The activities at students' discretion, such as taking care of children during summer camps, participating in local democratic civic initiatives, conference organisation, etc.

The picture emerging from the FGI exercise with students seems to demonstrate that the idea of the PWSZ 'social competence pilot module' appears to be adequate to the needs of some students more open to new experiences and developing their social competences. Some, however, may not be truly interested in participating in such activities initiated by the University. Designing the case study module revealed important weaknesses reported by the students, and, consequently, led to an unsatisfactory implementation of the module in some respects. Therefore, the case study module is likely to have a limited positive impact on students in terms of improvement of their social competences. Students expect their recommendations will significantly improve the relevance of the programme. Otherwise, in some students' opinions, the module should be withdrawn. 'Social competences' are perceived and discussed by students in relation to their future employment opportunities, rather than in terms of their responsibility for democracy, for the country or for local communities.

\section{Conclusion and recommendations}

Based on the above cases we can note that one standardised definition of social competences has not been developed in HEIs. The Latvian brief definition states that social competences involve an ability to cooperate, while the Czech definition focuses on communication and some professional aspects of education. The German case provides a more precise definition, which highlights 3 dimensions: (1) referring to human interrelations; (2) referring to key competences; (3) referring to work-oriented aspects of competences. In Poland we can notice a more formal approach, since social competences are directly listed in the Polish Qualifications Framework and can be incorporated in a general definition - an individual who has social competences is ready to perform some activities addressed to the society (in general), including also professional and cognitive skills. One of the reasons for this differentiation is a lack or unity in the national public policies concerning the issue at national levels. Thus, although diversity of meanings does not inhibit forming social competences by universities themselves, nevertheless, common reflection on the social competences of graduates at national and European levels affecting public policies could result in a better fulfilment of this essential task of higher education. 
The cases outlined allow for identifying a number of challenges for shaping social competences in HE graduates:

- The lack of national policies directly addressing social competences in tertiary education. Although the importance of social competences remains unquestioned, there are not any motivators (other than personal motivation of academic community members) for HEIs to include them in the programmes.

- Quality Assurance Agencies (QAAs) do not motivate HEIs to incorporate and assess social competences in their programmes. They do not assess or verify the development of social competences in evaluated programmes or institutions. The accreditation process is focused on meeting some measurable standards and criteria (codified). Social competences, due to their diversity, pose some difficulty in terms of codification. As a result, QAAs do not include them in a broader scale over the accreditation process.

- Social competences are not perceived as an objective in HEIs programmes, despite their importance equal to that of knowledge or other skills. We can observe a diversified level of formality in HEIs approach towards social competences: from delivering social competences as 'a side-effect' of education, mainly aimed at professional or research development to the designed modules and centres intentionally focused on them.

Based on our research we could formulate a number of recommendations. Undoubtedly, in view of contemporary challenges originating from demographic, climate, technological, digitalisation and many other problems, forming social competences should be a primary objective of tertiary education. In the times of VUCA (Volatility, Uncertainty, Complexity and Ambiguity), only uncertainty seems to be certain. To deal with the uncertain future the graduates need to be equipped by the whole education system and the teaching/learning process with social competences helping them to face these challenges.

Therefore, our most general, but at the same time most critical recommendation (see: Dasche IO8, 2020; Brdulak, Chmielecka et al., 2020) is to create space for debates and discussions about social competences. Decision makers at all levels - from European to institutional ones, as well as teachers and students must be offered enough room to discuss all crucial issues connected with social competences, e.g. how to develop social competences in higher education programmes, how to assess social competences, how to design supporting learning outcomes enhancing the achievement of social competences, how to evaluate programmes focused on social competences, what good practices can be specified, etc. This debate should adhere to European and universal values; also, it should not be conducted exclusively in the 4 researched countries, it is recommended that the whole EHEA is involved. It should 
have a global impact, since global challenges require a global response. It is believed that a similar debate will result in better understanding of our diversity, as well as in promoting the issue of social competences. Another result of the debate might be a better cooperation between students and HEI teachers on developing new programmes, which would help both parties involved to learn from each other.

At national levels, decision-makers should provide legislative and other formal support to include social competences into official tasks of higher education. First of all, conceptualisation of social competences is needed as well as opening research/ innovation programmes focused on social competences development, financial support to HEIs initiatives in the area e.g. for training of academic teachers, etc. As an element of tertiary education, social competences should be an element of external evaluation of programmes. National quality assurance agencies should be engaged to promote importance of social competences and methods of their assessment. National guidelines how to link non-formal and informal learning into formal programmes can be useful in recognising and validating social competences achieved as a prior learning (RPL).

At the European level, the recommendation is to re-edit the Bologna Qualifications Framework and European Qualifications Frameworks to strengthen the importance of social competences formation in the education process. The European Standards and Guidelines on quality assurance for the EHEA should be re-edited, too. Creation of a system for exchanging good practices in designing, assessing and validating social competences in the EHEA as well as more new programmes/projects supporting activities for this issue should be parallel actions to changes in official European policies.

\section{Bibliography}

Boyadjieva, P., Ilieva-Trichkova, P. (2018). Adult education as a common good: conceptualisation and measurement. International Journal of Lifelong Education, 37(3): 345-358, DOI: 10.1080/ 02601370.2018.1478458

Brdulak, J., Chmielecka, E. et al. (2020). [Brochure] Model solutions regarding developing, assessing and validating social competences in higher education, including recommendations for levels of: HE Institutions, national policy making and EU policy making. Warszawa: SGH / DASCHE ISBN: 978-83-8030-349-2

Collins, B., van der Wende, M. (2002). Models of Technology and Change in Higher Education, CHEPS. Retrieved from: https://research.utwente.nl/en/publications/models-of-technologyand-change-in-higher-education-an-internatio (accessed: 8.02.2020). 
DASCHE IO1(2018). Methodology for Preparing Country Reports. Intellectual Output 1 of the DASCHE project: Development, assessment and validation of social competences in higher education. Retrieved from: http://www.dasche.eu/system/files/publikacje/DASCHE_ Methodology_Report.pdf (accessed: 12.11.2019).

DASCHE IO8(2020). Model solutions regarding developing, assessing and validating social competences in higher education, including recommendations for levels of: HE Institutions, national policy making and EU policy making. Intellectual Output 8.

EUA (2018). Trends 2018. Learning and teaching in the European Higher Education Area.

Gedviliene, G., Gerviene, S., Pasvenskiene, A. et al. (2014), The Social Competence Concept Development in Higher Education. European Scientific Journal 10(28).

Giroux, H.A. (2014). Neoliberalism's War on Higher Education. Chicago: Haymarket Books.

https://eua.eu/downloads/publications/trends-2018-learning-and-teaching-in-the-europeanhigher-education-area.pdf (accessed: 12.11.2019).

https://www.oecd.org/education/2030/E2030\%20Position\%20Paper\%20 (5.04.2018).pdf (accessed: 12.11.2019).

https://www.un.org/ga/search/view_doc.asp?symbol=A/RES/70/1\&Lang=E (accessed: 12.11.2019).

Kuh, G.D. (2019). Why Skills Training Can’t Replace Higher Education. Harvard Business Review. Retrieved from: https://hbr.org/2019/10/why-skills-training-cant-replacehigher-education?utm_medium=social\&utm_campaign=hbr\&utm_source=linkedin (accessed: 15.11.2019).

Macioł, S. (2012). Kwalifikacje i kompetencje absolwentów szkół wyższych - perspektywa pracodawców. Nauka i Szkolnictwo wyższe 1(39): 34-54.

Moon, J., Orlitzky, M. (2011). Corporate social responsibility and sustainability education: A trans-Atlantic comparision. Journal of Management and Organization, 17: 583-603.

Mulder, M., Weigel, T., Collins, K. (2006). The concept of competence concept in the development of vocational education and training in selected EU member states. A critical analysis. Journal of Vocational Education \& Training, 59: 65-85.

Nantl, J., Černikovsky et. al. (2010). National Qualification Framework Tertiary Education in the Czech Republic, Prague: Ministry of Education, Youth and Sports.

OECD (2018). The future of education and skills. Education 2030.

Oria, B. (2012). Enhancing higher education students' employability: A Spanish case study. Journal of Technology Management and Sustainable Development 2012/11(3): 217-230.

Paris Communiqué (2018, May 25 ${ }^{\text {th }}$ ). Retrieved from: http://www.ehea.info/media.ehea.info/file/ 2018_Paris/77/1/EHEAParis2018_Communique_final_952771.pdf (accessed: 12.11.2019).

Sá, M.J., Serpa, S. (2018). Transversal Competences: Their Importance and Learning Processes by Higher Education Students. Educ. Sci., 8: 126.

Szerląg, A. (Ed.) (2009). Kompetencje absolwentów szkół wyższych na miarę czasów. Wybrane ujęcia. Wrocław: Atut.

Teichler, U. (2003). The future of higher education and the future of higher education research. Tertiary Education and Management, 9(3): 171-185. DOI: 10.1080/13583883.2003.9967102 
Ten Dam, G.T.M., Volman, M.L.L. (2007). Educating for adulthood or for citizenship: social competence as an educational goal. European Journal of Education, 42(2): 281-298.

United Nations (2015). Resolution adopted by the General Assembly on 25 September 2015: Transforming our world: the 2030 Agenda for Sustainable Development.

University of Bremen, Institute Technology and Education ITB (2019). Country report - Germany. Retrieved from: http://dasche.eu/system/files/publikacje/country\%20_report_Germany. pdf (accessed: 14.08.2019).

Walker, M., McLean, M. (2013). Professional education, capabilities and the public good: The role of universities in promoting human development. Abingdon, NY: Routledge.

Weinert, F.E. (2001). Concept of competence: A conceptual clarification. In: Salganik D.S., Defining and Selecting Key Competencies. Seattle: Hogrefe \& Huber: 45-65. 